\title{
Students' Self-Efficacy Towards Assignment In The Form Of Infographic In Biology of The Cell Courses
}

\author{
Adam Fernando \\ \{adamfernando@umrah.ac.id $\left.{ }^{1}\right\}$ \\ Universitas Maritim Raja Ali Haji, adamfernando@ umrah.ac.id ${ }^{1}$
}

\begin{abstract}
The COVID-19 pandemic has a huge impact on many aspects of life, including education. Some efforts should be taken to ensure that learning objectives are achieved. One of such is giving the assignments in the from of infographics, especially in Biology of The Cell courses. Subsequently, this study used a descriptive approach and aims to determine student self-efficacy regarding the assignment of infographic preparation in the course. From the results, the student's self-efficacy for giving assignments in the form of compiling infographics in the course was in a good category.
\end{abstract}

Keywords: self-efficacy, assignment, infographics, the biology of the cell.

\section{Introduction}

The COVID-19 pandemic has a huge impact on every aspect of life including, the economic, social, health, and educational systems. Due to this pandemic, educators in this case lecturers must be able to organize an effective and efficient learning process as well as adjust fast and precisely to the current environment. Certain efforts must be performed during the learning process to ensure that students receive knowledge effectively and educational goals are achieved. One of such efforts is the use of appropriate recitation or assignment methods adapting according to current conditions.

Students in universities might be given assignments in a variety of formats. In the current pandemic, the assignments given should be performed independently and be completed without having to meet face-to-face with lecturers to help curb the spread of COVID-19. It does not need to be many, therefore students do not feel burdened by the learning process. Creating infographics possibly facilitates a good learning process during the pandemic situation.

Infographics are a medium that combines text, pictures, schematics, and tables into a concise presentation to convey a collection of vital information. The developed infographic aims to improve the efficiency with which messages are delivered to readers. According to [1], infographics are a form of information delivery that demonstrates the use of good graphic design to improve human ability to understand a certain pattern. They have become a new trend that can be used in the learning process, including Biology of The Cell courses. [2]

According to the analysis of the semester learning plan for the Biology of The Cell course at the Universitas Maritim Raja Ali Haji (UMRAH), the material contains a lot of information that needs contextual explanation. Therefore, providing a method that helps students understand even though they cannot conduct direct observation in everyday life becomes necessary. This is the foundation for students to effectively visualize the Biology of The Cell material through the 
task of generating infographics. Hence, this study aims to determine student self-efficacy regarding the assignment of infographic preparation in the Biology of The Cell course.

\section{Methods}

From June-December 2020, a descriptive study was performed. Purposive sampling was used to select 31 students who took the Biology of The Cell course in the Odd Semester 20202021 at the Universitas Maritim Raja Ali Haji. Subsequently, data were obtained through questionnaires distributed online to students after attending the lectures for one semester. This was then analyzed descriptively and quantitatively and the aspects of the assessment acquired were categorized into a modified interpretation of [3] in Table 1.

Table 1. Category of Self-Efficacy Assessment.

\begin{tabular}{ll}
\hline \multicolumn{1}{c}{ Percentage } & \multicolumn{1}{c}{ Category } \\
\hline $0 \%-24 \%$ & Not very good \\
$25 \%-49 \%$ & Not good \\
$50 \%-74 \%$ & Good \\
$75 \%-100 \%$ & Very good \\
\hline
\end{tabular}

\section{Result and Discussion}

Ten modified questions are used to assess students' self-efficacy toward tasks in the form of infographics [4]. This is important in determining the level of students satisfaction after working on infographic assignments. Table 2 shows the results of the analysis.

Table 2. Results of Analysis on Student Self-Efficacy on Assignments in the form of Infographics

\begin{tabular}{|c|c|c|}
\hline No. & Statement & Highest Percentage \\
\hline 1. & These assignments can increase my motivation to learn. & $54.8 \%$ (Strongly Agree) \\
\hline 2. & $\begin{array}{l}\text { I can improve my visual literacy to understand the concepts through an } \\
\text { assignment in the form of infographics. }\end{array}$ & $54.8 \%$ (Agree) \\
\hline 3. & $\begin{array}{l}\text { In my opinion, giving these assignments can increase my imagination to } \\
\text { understand the biology of the cell material. }\end{array}$ & $61.3 \%$ (Strongly Agree) \\
\hline 4. & $\begin{array}{l}\text { In my opinion, giving these assignments can increase my creativity to } \\
\text { compose a good infographic. }\end{array}$ & $74.2 \%$ (Strongly Agree) \\
\hline 5. & $\begin{array}{l}\text { I can master new skills that I have never encountered in my daily life } \\
\text { through this assignment. }\end{array}$ & $71 \%$ (Strongly Agree) \\
\hline 6. & $\begin{array}{l}\text { In my opinion, learning by giving this assignment can positively affect } \\
\text { the learning process. }\end{array}$ & $64.5 \%$ (Strongly Agree) \\
\hline 7. & $\begin{array}{l}\text { In my opinion, this infographic is a tool that is capable to present scientific } \\
\text { information. }\end{array}$ & $64.5 \%$ (Strongly Agree) \\
\hline 8. & $\begin{array}{l}\text { In my opinion, infographics can show the material in a form that is easy } \\
\text { to understand. }\end{array}$ & $67.7 \%$ (Strongly Agree) \\
\hline 9. & $\begin{array}{l}\text { It is easier for me to understand the material by using infographics than } \\
\text { plain text. }\end{array}$ & $58.1 \%$ (Agree) \\
\hline
\end{tabular}




\begin{tabular}{ccc}
\hline No. & Statement & Highest Percentage \\
\hline 10. & $\begin{array}{l}\text { In my opinion, giving this assignment can help me to understand the } \\
\text { biology of the cell material from the complex into simpler ones. } \\
\text { Mean (Category) }\end{array}$ & $64.5 \%$ (Strongly Agree) \\
& $63.54 \%$ (Good)
\end{tabular}

According to Table 2, students gave good self-efficacy towards infographic assignments in general. From the results, 17 students $(54.8 \%)$ strongly agree with the statement that they can feel a high motivation to learn. Furthermore, with the same number and percentage of students felt that they could improve their visual literacy to understand the concepts studied. Both are based on the opinion [5] that infographics can be created using graphic design to produce a good visual appearance. Infographics help to motivate learners and increase visual literacy, evaluation, persuasion, and visual communication.

Subsequently, 19 students $(61.3 \%)$ strongly agreed that this infographic assignment could improve their imagination needed to understand the abstract concepts of Biology of The Cell. Meanwhile, 23 students $(74.2 \%)$ felt that their creativity in compiling a good infographic was increased due to infographic assignments. [4] The imagination and creativity of students have been discovered to increase, once they are challenged with the creation of infographics. This is supported by the opinion of [6] that the human brain recognizes and understands patterns and their relationships, especially in visual forms that support students' imaginations in compiling infographics based on the studied material.

The complex Biology of The Cell materials can be simplified into an infographic display that can be created by students according to their respective abilities using an attractive and simple presentation. Also, data shows that 22 students $(71 \%)$ strongly agree that giving assignments in the form of infographics, allows them to acquire new skills that would not have been learned otherwise.

Students are instructed to create this infographic using a simple application, namely Microsoft Word and PowerPoint. This enables students to focus on making simple infographics without thinking about downloading other applications that require a good internet connection. However, based on the results of interviews with some students, two other applications were also used besides those instructed, namely Canva and CorelDraw. Canva is used by 20 people $(64.51 \%)$, and CorelDraw is used by 7 people $(22.58 \%)$, while the rest use PowerPoint. Moreover, Canva and CorelDraw applications were new applications and they never studied before. This indicates that the use of infographics reinforces students' perceptions of a good learning process. Students also obtained additional skills by learning the application on an autodidact basis in the infographic creating process.

Additionally, 20 people $(64.5 \%)$ strongly agree that this infographic is a tool for presenting scientific information and according to [5], infographics can be used as a scientific research tool. Students are expected to present content from reference materials as directed by the lecturer. For example, [7]'s textbook contains all information about Biology of The Cell courses, starting from the structure, function, and working mechanism of each cell component being studied. This book is very dense in content, therefore students may offer a straightforward display of information while maintaining scientific knowledge with this infographic assignments.

Furthermore, 21 students $(67.7 \%)$ felt that the material from books and teaching materials could be simplified into an infographic display that was effective to understand. A total of 18 students $(58.1 \%)$ believed that infographic assignment enables students to understand the topic easier than ordinary text-based data or information. This can assist students to grasp difficult 
things by breaking them down into smaller ones, which were assessed by 20 people $(64.5 \%)$. Students also believe that they can present infographics to help in simplifying the complex Biology of The Cell material. All aspects of this assessment were consistent with the opinion of [8] that infographics have the advantage of presenting materials in a more organized manner so that informative messages can be effectively received by others. Infographics can simplify complex information for easy understanding and based on the average percentage of student self-efficacy analysis results of $63.54 \%$, they are in a good category.

\section{Conclusion}

This study concludes that the students have a high level of self-efficacy during the compilation of infographics for assignments. Therefore, positive motivation, creativity, imagination, and learning process are demonstrated during the Biology of The Cell course. The results can be used as a basis for further studies on the usage of infographics both in schools and universities.

Acknowledgments. Gratitude goes to LP3M UMRAH, Department of Biology Education, Faculty of Teacher Training and Education UMRAH for facilitating this study. This extends to all students of the Department of Biology Education in UMRAH that participated.

\section{References}

[1] Lyra, KT, Isotani, S, Reis, RCD, .... Infographics or graphics+ text: Which material is best for robust learning?. 2016 iee 16th $\ldots$. ieeexplore.ieee.org; 2016;. Available from: https://ieeexplore.ieee.org/abstract/document/7756999/

[2] Apriyanti, N, Shaharom, MSN, Rahim, SSA, .... Needs Analysis Of Infographic As A Learning Media For Physics Teachers In Indonesia. ... : Jurnal Kurikulum \& ... ojie.um.edu.my; 2020; Available from: http://ojie.um.edu.my/index.php/JUKU/article/view/22201

[3] Fernando, A. Respon Mahasiswa terhadap Proses Pembelajaran Biologi Melalui Google Classroom di Universitas Maritim Raja Ali Haji. Pedagogi Hayati. ojs.umrah.ac.id; 2020;. Available from: https://ojs.umrah.ac.id/index.php/pedagogihayati/article/view/2335

[4] Bicen, H, Beheshti, M. The psychological impact of infographics in education. ... . Broad Research in Artificial Intelligence and ... brain.edusoft.ro; 2017;. Available from: https://brain.edusoft.ro/index.php/brain/article/view/733

[5] Ozdamli, F, Ozdal, H. Developing an instructional design for the design of infographics and the evaluation of infographic usage in teaching based on teacher and student opinions. EURASIA Journal of Mathematics, Science and ... ejmste.com; 2018;. Available from: https://www.ejmste.com/article/developing-an-instructional-design-for-the-design-of-infographicsand-the-evaluation-of-infographic-5337

[6] Siricharoen, WV, Siricharoen, N. Infographic utility in accelerating better health communication. Mobile Networks and Applications. Springer; 2018;. Available from: https://doi.org/10.1007/s11036-017-0900-3

[7] Alberts, B, Johnson, A, Lewis, J, Morgan, D, Raff, M, .... Molecular biology of the cell. taylorfrancis.com; 2017; Available from: https://www.taylorfrancis.com/books/mono/ 10.1201/9781315735368/molecular-biology-cell-bruce-alberts-alexander-johnson-julian-lewisdavid-morgan-martin-raff-keith-roberts-peter-walter-john-wilson-tim-hunt

[8] Yıldırım, S, Yıldırım, G, Çelik, E, Aydın, M. Student opinion about infographics design process. Journal of Research in Education and Teaching. jret.org; 2014;. Available from: http://jret.org/FileUpload/ks281142/File/24a.yildirim.pdf. 